Participating is more important than winning.

The Impact of Socio-Economic Change on Commoners'

Participation in eighteenth and nineteenth-Century Flanders

Paper for the13th Biennial Conference of the International Association for the Study of the Commons (IASC)

By

Dr. Tine De Moor

Associate professor in social and economic history

Department of History, Faculty of Humanities

Drift 10

3512 BS Utrecht

The Netherlands

0031302536458 


\title{
Participating is more important than winning. The Impact of Socio-Economic Change on Commoners' Participation in eighteenth and nineteenth-Century Flanders ${ }^{1}$
}

\author{
Tine De Moor ${ }^{2}$
}

Approx. 8352 words

\begin{abstract}
In literature on the use of common land, commoners are usually considered as a group. In this article the participation profile of commoners of a Flemish case-study is reconstructed in order to identify their individual motivation for using the common, in some cases becoming a manager of that common, and in some cases do no more than simply claim membership. Nominative linkage between the membership lists, book keeping and regulatory documents of the common on the one hand, and censuses and marriage acts on the other allow us to link the behaviour of the commoners to their the social-economic background. It becomes clear why some decision have been taken - e.g. to dissolve a nevertheless well-functioning cattle registration system - and how these affected the common the resource use of the common during the eighteenth and early nineteenth century. It explains how internal shifts in power balances amongst groups of active users and those who do not have the means or willingness to participate can jeopardize the internal cohesion of the commoners as a group.
\end{abstract}

\section{Keywords}

Long-term development, participation, group dynamics \& behaviour

\section{INTRODUCTION}

Comparative historical research on common land has increased our understanding of how common property regimes regulated access and management of their resources. Throughout Europe there are clear similarities in the way commoners tried to restrict access and use of those resources, and researchers have found much evidence that regulating mechanisms were sufficiently dynamic to cope with severe external stresses. We also know that commoners were usually very involved in setting up and changing the regulations and keeping an eye on the implementation of the rules. One of the issues that has been overlooked, however, in understanding why the rules of such bottom-up organizations were changed, is the internal composition of the group of commoners. Although historical researchers have generally assumed that commoners were a homogeneous group, with enclosures having had a similar effect on each of the group members, evidence from nonhistorical research suggests that the size of these groups, and their internal

\footnotetext{
${ }^{1}$ I would like to thank Maarten Prak, Jan Luiten van Zanden and Bas van Bavel for their useful comments on the first draft of this article.

2 Tine de Moor is associate professor in social and economic history at the Department of History, Faculty of Humanities, Utrecht University.
} 
heterogeneity, influenced their functioning, and potentially also their vulnerability to external attempts to dissolve their common property regime. ${ }^{3}$

In historical research on commons groups are usually considered to behave as homogeneous entities, and little attention is paid to the motives and backgrounds of the individual commoner. Given that the enclosures were mainly a governmentorchestrated procedure, with little attention to the effect it would have on the powerless individual farmers who lost their rights, this emphasis is quite understandable. ${ }^{4}$ If we consider the composition of these groups of commoners, however, we can assume each individual must have experienced the demographic, economic, social changes, and threats in a different way. Very likely each individual commoner's interests in the use of the resources - and his behaviour as a member of the group - must have varied greatly, and changes in individual behaviour may have had considerable consequences for the resource use of the entire common. Experimental research has shown that studying this behaviour is absolutely necessary to understand the processes involved in environmental degradation, processes which might have been going on before the privatisation of the commons from above (Jager et al. 2005). Moreover, the way in which commoners experienced the potential of the common in their daily life and changes herein, may have affected their willingness to defend their rights and thus may have influenced the speed of the privatisation process.

In order to link changes in behaviour with the consequences they may have had for the resources used, we need to focus on the types of interaction found, and find ways to distinguish between different types of behaviour, both in terms of the types of usage and in terms of the intensity to which the common resources were used. For most of the European commons, grazing was probably the most frequently offered "facility". Despite the fact that many commoners would have had some animals, grazing was often restricted to cows and horses, excluding those commoners who had only smaller animals, such as pigs, geese or goats. Other commons resources such as wood - or the possibility of earning some money on the common by performing odd jobs could enable users of the commons to become members of the

\footnotetext{
${ }^{3}$ I have not found any historical studies on commons that actually considered the effect of group size and heterogeneity on the behaviour of commoners or on the functioning of commons. If we consider other than purely historical literature, Mancur Olson (1982; see also De Moor 2003b) was the first to refer to the effect of group size, who claims that collective action becomes less effective when groups become larger. His work has been challenged by authors such as Oliver and Marwell (1988), who claim that Olson incorrectly believed that larger groups are less likely to support collective action than smaller ones. They claim that the effect of group size depends on cost. If the cost of collective goods increases with the number who share in them, larger groups act less frequently than smaller ones. If the cost varies little with group size, larger groups should exhibit more collective action than smaller ones because larger groups have more resources and are more likely to have a critical mass of highly interested and resourceful actors. The positive effects of group size increase with group heterogeneity and social ties. Other scholars, such as Brewer and Kramer (1986), have focused on the psychological effect of group size.

${ }^{4}$ Whereas some of the eighteenth century rulers (such as Maria Theresia) had proposed - though unsuccessfully - social ways of subdividing the commons, the mid-nineteenth century legislation of many continental European governments that aimed at the dissolution of the commons was as ruthless. Most of the commons in Western Europe had disappeared by the end of the nineteent ${ }^{\mathrm{h}}$ century. Elsewhere in continental Europe they were considerably reduced. The most comprehensive overviews in this regard are given by the edited volumes of M.-D. Demélas and N. Vivier (2003)) and Congost and Lana (2007).
} 
common and (sometimes) pay a membership fee. ${ }^{5}$ Commoners could thus have a variety of profiles, from active users and managers to members who hardly ever showed up at meetings, from users whose main interest was grazing cattle on the common or performing jobs for the common, to those who saw the common as a way to increase their prestige within the village by fulfilling functions on the board.

Apart from such potential differences in terms of use, there might also have been considerable variety in the degree to which commoners needed or had the means to use the common's resources. Strangely enough, in commons literature the possibility that members were not actively involved in using or managing their common land is not even considered. It seems to be viewed as a given that those who obtained the right to use the common would also graze cattle on it, or at least try to obtain benefits in another way, for example by becoming a member of the commons board, and thus gaining social status. These assumptions derive from two frequently expressed assumptions, which are part of the enclosure debate. First, much of the literature assumes that commoners were poor by definition, and that they would seize any opportunity for extra sources of income (Hammond 1995). Yet, if the main advantage of a common was obtained from having cattle, many poor commoners would be automatically excluded from its benefits and even those with cattle, may have had reasons not to become active users of the common. Distinguishing participants on the basis of their occupation as has been done by for example Leigh Shaw Taylor (2002) is a first step towards understanding differences in their participation, but - as will be shown in this article - other issues like the use of the common in various stages of the commoners' life cycle might even tell us more about the reasons to use or not to use the common.

Second, central to a different debate on the use of the common and its effect on natural resources is the idea that common land could be easily overexploited because individual commoners tried to maximize their incomes. Many scholars involved in this debate are defeatist and view this maximization as having eventually led to a tragedy for the commons. ${ }^{6}$ This "tragedy" refers to a long-standing debate on the use of common pool resources, that was started by the American biologist Garett Hardin. In his seminal article, entitled 'The tragedy of the commons' (1965) Hardin claimed that each individual that would be allowed access to a collective resource would react in the same way: they would think of their own benefits in the short run, not of the collective benefits in the long run. His main concern hereby is that population growth in the future - from his 1968-perspective - would lead to overharvesting of the world's resources and eventually lead to a tragedy. He exemplified this with an example, and indirectly also referred to a historical situation. He pictures a common pasture that could be used by everyone. As long as natural and demographic disasters decimate the cattle and the farmers once in a while, the pressure on the pasture's resources remains under the critical level. However, as soon as there is prosperity, population growth and sufficient cattle, there will be

\footnotetext{
${ }^{5}$ Whether the payment of a membership fee was needed depends on the local "access rules". In some cases being a villager was sufficient to claim rights, elsewhere being a tenant would have given access rights. For a discussion of access rights within North-Western Europe, per country, see the different chapters in De Moor, Taylor, and Warde (2002a)..

${ }^{6}$ Elsewhere I have made an overview of the literature on commons according to the authors' view on commons, and I have explained how their views on the economic, ecologic and social meaning of the commons is mostly intertwined. See De Moor (2007).
} 
overexploitation. He hereby assumed that individuals are unable to communicate and organise in such a way that they can actually prevent - themselves and others - to overharvest the resources and secondly, he assumed that the nature of man is such that greed and selfishness will always lead to free-riding and subsequently overexploitation. Although the metaphor "the tragedy of the commons" has been extremely popular both in different scientific disciplines and among policy makers, many researchers have since his publication given proof of the opposite: individuals commoners and others - are capable of preventing freeriding, by amongst others institution-building. In many examples of collective use of resources today and in the past, commoners device rules, sanctions and instruments to restrict their own behaviour, to a level that allows long-term use without significant overuse. ${ }^{7}$ One of the issues that is hardly acknowledged however is the possibility that some commoners may not use the common at all, even though they have the right to do so. This seems to run counter to the idea of the way a homo economicus (the average commoner) is supposed to act, namely use more than one would even need for himself, so that a profit could be made out of the surplus harvest. It even seems to run counter to the idea of those who belief in the capabilities of commoners to avoid tragedies, as literature does not study this phenomenon. The analysis of the commoners' individual behaviour of our case study proves, however, that the influence of those who do not participate can be of significant influence on the group as a whole.

Taken together this article starts from the assumption that commoners formed a far more heterogeneous group than is usually supposed, and that the individuals motivations and decision power within the group may have changed the overall management over time more than has been previously assumed. Distinguishing such profiles according to the kind of interaction that took place between the members and the common will help us to distinguish groups of users of the commons, as well as summarize individual changes in the behaviour of these members into more general trends. Because a large part of the decision-making on the commons was conducted in a democratic way, through general and ad hoc meetings, it can be assumed that the changes in individual profiles may have affected not only their own use of the resources, but also their decisions about access to the commons and the use and management of resources in general. The board of the common - usually elected was responsible for the daily management but it were usually the commoners that decided upon the long-term management strategy. Summarised, the effect of the individual user on the collective management is what we are trying to unravel in this article. Rather than analyzing how regulation affected the commoners, both as a group and as individuals, we will concentrate on the opposite question: how did (changes in) the commoners' daily life affect regulation and functioning of the common? And: can we explain why certain decisions were taken?

\footnotetext{
${ }^{7}$ The main advocate of the claim that commoners are indeed able to make their common work and avoid overexploitation is 2009 Nobel prize winner Elinor Ostrom (see her book Governing the commons (1996)). Amongst historians Susan Cox (1985) was long the only scholar who offered historical counterevidence for Hardin's theory. In the meanwhile this group of historians has now grown, and various projects on the team of commons, and their exploitation are currently running. There is even an association - the International Association for the Study of the Commons - that is entirely devoted to bringing together scholars from all over the world who study the functioning of the commons.
} 
This article continues with a brief explanation of how relationships between group size, heterogeneity, and the functioning of a common were perceived in our research, thus offering a framework for understanding how we can study such factors in a historical context. Second, a case study that offers sufficient material to study such relationships is introduced. On the basis of very detailed nominative analyses, it was possible to evaluate the behaviour of a large group of commoners over nearly two centuries in terms of participation type and intensity. By scrutinizing the intensity and diversity of their participation in activities on the common, we can explain certain changes in their behaviour as a group with respect to the use of resources, the involvement of non-members in commons' management, and their willingness to engage in charity towards poor members and other needy persons of the same village community. Because no similar analysis of group behaviour for this group has been done, it is difficult to compare it to other case studies. ${ }^{8}$ In the conclusion I will provide some suggestions for further comparative research on this topic.

\section{CASE STUDY: GEMENE AND LOWEIDEN COMMON IN THE VILLAGES OF ASSEBROEK AND OEDELEM, FLANDERS}

Determining the impact of individuals on group decisions and the effect of the heterogeneity of the group on common resources is in many cases very difficult or impossible, as records of the activities on the common have generally not been preserved. ${ }^{9}$ Nevertheless, for some commons there is sufficient archival material to reconstruct the day-to-day activities on the common that involved both commoners and outsiders. For the common meadow of Gemene and Loweiden - extended over two villages just outside the city of Bruges, Assebroek and Oedelem - we have almost the complete financial records (accounts) for the eighteenth and nineteenth centuries. ${ }^{10}$ In combination with the preserved lists of commoners - including their dates of first membership in the common, and information about relatives who served as proof for their claims - and biographical information retrieved from other archival sources such as marriage registers, ${ }^{11}$ we have sufficient data to see how commoners behaved as individuals, e.g. when (in their lives) and how many cattle they had on

\footnotetext{
${ }^{8}$ In experimental sociology the effect of micro-level processes (such as individual behaviour) on macro-level outcomes is studied, but in an entirely different way. See for example, Jager (2000) how a homo economicus and homo psychologicus act in an experimental commons dilemma situation. $\mathrm{He}$ concludes that the incorporation of a micro-level perspective on human behaviour within integrated models of the environment yields a better understanding and eventual management of the processes involved in environmental degradation.

${ }^{9}$ Group size and internal heterogeneity of the group are two issues that are receiving increasing attention among students of present-day commons. The issue of group size has been around since Mancur Olson's ground-breaking study on collective action, however, no consensus exists about the role played by this factor and the factor of group heterogeneity in the management of the common and the use of the resources. According to Poteete and Ostrom (2004) this is due to a lack of uniform conceptualization of these factors, the existence of non-linear relationships, and the mediating role played by institutions. They come to the conclusions that: some forms of heterogeneity do not negatively affect some forms of collective action. Institutions can affect the level of heterogeneity or compensate for it. Group size appears to have a non-linear relationship to at least some forms of collective action

${ }^{10}$ See the archival records numbered 59 to 124 of the archives of the Gemene en Looweiden preserved in the City Archives of Bruges. An extensive description and an inventory of the sources preserved for this particular common can be found in De Moor (2005).

${ }_{11}$ I used both parish registers for the seventeenth to eighteenth century that listed data on birth, marriage, and burial, and nineteenth-century population registers, in particular those on marriage, for the villages of Assebroek, Oedelem, and a number of surrounding villages.
} 
the common, whether they participated in general meetings, etc. And it will allow us to reconstruct how their behaviour influenced use and management. We especially examined the effect of social-economic heterogeneity, measured mainly by individuals' occupations (whether they were independent farmers or wage earners) and the possession of cattle, which could be retrieved from various eighteenth and nineteenth century agricultural censuses that were linked to the archival records of the case-study. Once a "profile" of the commoners is made, group heterogeneity is compared with the involvement of individuals in the activities of the common by looking at their type of activity and activity rate, and link this to on the one hand management decisions taken and on the other hand more general demographic and social-economic changes. However, before analyzing and explaining the behaviour of the commoners, I will provide more details on how access to and use and management of the common was regulated in this particular case and which sources we could use to for our study. ${ }^{12}$

Membership in the Gemene and Loweiden was strictly regulated and limited by inheritance. ${ }^{13}$ Only those able to prove that their own or their wife's ancestors had been registered as common users could claim membership. The oldest charter concerning the rules of the common, dating from 1514, indicates that initially women were not excluded from membership, and indeed, until the middle of the seventeenth century, a few female names can be found in the membership registers (the hoofdboeken). ${ }^{1415}$ Those who obtained the right of membership via their wife ('by causen van huwelike alleenlick') could only use this right as long as she lived. Although the partner could thereafter no longer claim use rights, each of the children born from this marriage would be entitled to claim use right. ${ }^{16}$ Members were referred to as aanborgers (or amburger, amborchteghe, ambuerdeghe), which can be explained as a corruption of the words aenboordig, aenbortig, or aenborchtig, meaning 'being in the possession of a good or a right' (De Bo 1892). ${ }^{17}$ The procedure to obtain that right consisted of a visit to the parish priest in the companionship of two witnesses that would confirm the applicant's descent from the entitled ancestors. After payment of the sum of one Flemish pound, the priest noted the name of the new aanborger in his impressive membership register, which he also consulted to

\footnotetext{
${ }^{12}$ See also Tine De Moor (2008).

${ }^{13}$ Although this is not the most regular way to restrict access to a common, restriction via inheritable rights is often found elsewhere in Europe as well. De Moor, Shaw-Taylor, and Warde 2002a, 261).

${ }^{14}$ In the first book several women are mentioned. In the act of 1514 it was stated that both women and men could become members ('zoo wat vrauwen ofte mannen die aen dese vrye geprivilegierde weede ende meersch van Assenbrouc amborchtich worden. ...'). See article 8 of the archival document no. 2 (late seventeenth century) of the archive of the Gemene and Looweiden (hereafter: AGL), City Archives of Bruges (hereafter: $\mathrm{CAB}$ ). For a complete overview of all the archival documents that can be found in the archive of the Gemene and Loweiden, see De Moor (2005).

${ }^{15}$ In July 1622, for example, the unwedded daughter Mayken van Ghistele, daughter of Absoloen, from the neighbouring village of Male became a member of the common. CAB, AGL 12, Hoofdboek. Boek van de geslachten van de Gemene en Loweede, 1622-1703.

${ }^{16}$ The regulation says: 'vrauwe ofte man, dan weduwe ofte weduwenare zynde, vervremt ende onbekent gherekent van zyn ambordtichede'. If they had children from a marriage with a rightful commoner, however ('kinderen commende vande voorseide ambortichede'), then these would remain commoners ('daer innen gherecht als amborteghe by generatie ende recht van hoirie van geboorten naer oude costumen'), CAB, AGL 2, art. 8.

${ }^{17}$ The name aanborger (or a variation) can also be found elsewhere. Gilliodts), for example, refers to an account of the heerlijkheid Zotschore (of 1547) in which was mentioned: 'Ontfaen ter causen van der herfvelicke rente van Zotschoore in veltschattinghe die diversche persoonen en de ambochten jaerlicx ghelden telcken S. Jans avende mits somers.'
} 
assure himself of the rights of the claimant's ancestors. This was a sum equal to a days wage and in the case of the Gemene and Looweiden it served as the only way to restrict the total number of entitled members. Elsewhere only village inhabitants were allowed or the poor of the village got specific advantages, but here no such restrictions could be found. ${ }^{18}$ This means that in principle inhabitants from far-away villages could claim use rights. Before the end of the nineteenth century - when the managers of the common considered a high number of registration as a way to prevent the government from claiming the land (see further) - this was however hardly the case. ${ }^{19}$ As we will see further on however, the commoners also came up with other ways to limit the total number of cattle on the common, in their attempts to prevent overexploitation of the pastures.

Several membership registers have been preserved, the oldest dating from $1515 .^{20}$ These lists are an important source for reconstructing the behaviour of the commoners, in combination with a number of other sources such as resolution books containing all the day-to-day decisions taken by the managers of the common that complemented the more general regulation written down in charters and referred to in the bookkeeping. In these last sources, all incoming and outgoing amounts were usually accompanied by the names of those involved. ${ }^{21}$ This information allows us to develop 'participation profiles' of all members, and of those who were involved in the common without being members. Some names are listed in the accounts of the common who are not real members. In addition to suppliers of beer, bread, or other commodities who usually weren't members, a frequent name mentioned is that of the Lord of Sijsele - a seignory that included amongst others the pasture of the Gemene en Loweiden -, who according to the earliest regulation had the right to (dis)approve of changes to regulations and the triannual bookkeeping. As for the rest of the activities on the common, the lord or his bailiff were hardly ever involved or allowed to interfere. We can therefore assume that the common functioned autonomously and that the commoners' actions (or lack of them) were hardly ever hindered by local or other governments until the end of the old regime (1796). Thereafter, as we will see, the common went through a process of reorganization that would eventually allow the local authorities to encroach on the common's resources and assets, although only temporarily.

This common did not differ significantly from others in the sandy area around Bruges (in Dutch: De Brugse Veldzone), which was covered mostly with woodland and waste, much of which was used in common. Most of these commons were referred to

\footnotetext{
${ }^{18}$ For an overview of access regulation on Flemish commons: see De Moor (2002)..

${ }^{19}$ Today the common even has members from overseas. Every three years they meet to elect a new board but the use of the common can in no way still be compared to its original use of the $18^{\text {th }}$ century and before.

20 The archive of the Gemene en Loweiden contains a number of original hoofdboeken or copies and a number of separate lists of aanborgers. Important for this article are the following sources: Rijksarchief Brugge (hereafter RAB), Aanwinsten 1984, 68, Bouck van de geslachten van de Gemeene weede. Register van inschrijvingen als aanborger van 1515 tot 1703; volgende nummers uit het Stadsarchief Brugge, AGL: 12, Hoofdboek. Boek van de geslachten van de Gemene en Loweede, 1622-1703; 13, Hoofdboek. Boek van de geslachten van de Gemene en Loweede, 1718-1767 (copy); 14 Hoofdboek. Boek van de geslachten van de Gemene- en Loweede 1769-1889; 15, Hoofdboek van de aanborgers 1889-1981. The hoofdboeken were not systematically foliated. Source references to these books hence do not refer to a specific place in the books.

${ }_{21}$ In the remainder of this article we refer to these aanborgers as members or rightful users of this common.
} 
as veld - to name just a few: Beverhoutsveld, Bulskampveld -, which refers to poor pasture land, often overgrown with heath and bracken. The case-study dealt with in this article is different in the sense that it was for the larger part a meadow, with good grass for the cattle and horses of the commoners. The downside of it however was that regular floodings - caused by the small river of Sint-Trudoledeken that bordered the common in the south - made the common pasture at times unfit for grazing. In those years when there was serious flooding, the pasture period had to be postponed with a few weeks. ${ }^{22}$

Apart from the vast stretches of heathland in the Campine area north of Antwerp and in the province of Limburg, this area around Bruges was the last are of Flanders were large plots of common land could still be found, until the middle of the nineteenth century. Access to the commons in the east of Flanders was however often less strictly regulated: usually all villagers could benefit from the resources on the common, whereas in the area around Bruges access was based on a number of conditions, of which descendance from a number of "original" families could be one. ${ }^{23}$ The way in which commons were organised in Flanders was not fundamentally different from elsewhere in Europe, notwithstanding the usual local differences. ${ }^{24}$ As elsewhere in North Western Europe, the Flemish commons came under fierce attack around the middle of the nineteenth century and nearly completely disappeared. In 1847 a national law set-off the massive sale and privatisation of most commons in the areas mentioned. ${ }^{25}$ The case study is however one of the very few that managed to survive that privatisation process, though not without difficulties. The local government repeatedly tried to encroach upon their property (see further in this article).

Our nominative analysis of the bookkeeping and resolution books was linked to data about the life-course of individual commoners. In particular, parish and population registers on birth/baptism, marriage, or death/burial, and the remaining individual files of population and economic censuses and tax registers contained large amounts of data that could be linked to the names of commoners. In many cases linking names was not very straightforward, but it nevertheless added up to a sample of 589 aanborgers for whom we have found sufficient biographic information. This does however not mean we have all significant biographic information (about birth, marriage and death), for all of these people. Depending on the kind of analyses, a selection was made of these 589 persons, that contained values for the variables needed, depending on the kind of analysis that is required for a specific research question. This dataset, combined with the more general data derived from censuses and population registers, gives us information about the way the common was run, as well as more general social-economic data, such as changes in the number of potential users, the price of cattle, changes in the type of agriculture etc. It provides a wealth of information on the effects of the commoners' behaviour on the common. For many individual commoners we were able to identify the period in their lives when they actively used the facilities of the common, and for a significant number we could also retrieve details about their professional lives and whether they had any cattle, which might have been put on the common. In our analysis the commoner's

\footnotetext{
22 See a full description in De Moor (2003b, 163-168).

${ }^{23}$ For a further explanation of the specificities of commons in Flanders, see De Moor (2002).

${ }^{24}$ See a comparison in conclusion De Moor et al. (2002b).

${ }^{25}$ See De Moor (2003a).
} 
cattle and horses that was mentioned in the bookkeeping as grazing on the common was compared to the overall number of cattle and horses mentioned in e.g. agricultural censuses. Usually these corresponded, or the number of cattle on the common was smaller than mentioned in the censuses, thus meaning that the commoner put only part of his animals on the common. All this information gives us a clearer picture of the economic importance of the common. It can be expected that the economic importance of the services and resources the common had to offer was especially important for understanding the participation behaviour of commoners, as the main advantage offered by membership in the common was that the common was a place to pasture cattle. ${ }^{26}$

In the rest of this article I make a distinction between different "types" of commoners, that can be found. Such a categorisation will help to distinguish certain trends in the participation. Overal there is the distinction between members and non-members: those with rightful claims on the common, and those without. Elsewhere in this article the conditions for membership have already been explained. Nevertheless individuals who were officially not entitled to use the resources as they could not fulfil the conditions were allowed. These are in this article often referred to as non-members. We also refer to the members as participants. The actual fact of registration is considered as an act of participant, but, amongst the participants there are both active and passive members, the last group being those commoners who did have the right to participate but did not use that right. Active participants can again be split up in two groups: those who remained simple users by putting cattle on the common, or harvesting wood, but also by receiving payments from the common for doing some small jobs like repairing fencing. For this article no distinction has been made between those two groups, as in the end their relationship to the common was the same: they both benefitted from being a member, albeit in different ways. A second group to be distinguished is that of those active participants who choose to move up the social hierarchy within the common and become a manager. These managers were elected among the regular members and would remain in power for several years. The made sure that the daily functioning of the common was secured, including jobs such as sanctioning wrongdoers, reporting to the bailiff, organising the meetings etc. I have chosen to make a distinction between both as it seems already clear on the basis of the reports on the common, that something was going on in terms of power delegation and balance, from the middle of the eighteenth century onwards. What precisely, and how this can be explained will follow hereafter.

The commoners' changing social-economic backgrounds and their participation in the management of the common

A comparison of the names of members with the names that appear in the bookkeeping and resolution books yields a striking and unexpected result. While it is reasonable to suppose that members are also those who actually used the common, that seemed not necessarily the case. It was not at all unusual to become a member and then never to appear again in the written documents of the common: some

\footnotetext{
${ }^{26}$ Because not all the data on the lives (date of birth, death, marriage, etc.), work (occupation), and property (especially ownership of cattle) could be retrieved for all commoners, I have used a number of samples for the analysis. The sample that was used to retrieve the occupations of the aanborgers does to a certain extent include periods other than the sample used to analyze the average age at which the aanborgers became commoners.
} 
commoners simply never used their right to pasture cattle or to participate in any other way. Given the large amount of sources the data are based on and their high quality, we can assume that the absence of some members in the sources was not a coincidence. In most cases commoners' names could be found year after year with a cow to graze, or they were commons officials who reported regularly about their activities. But, as mentioned, there were a number of registered commoners who did not participate at all, not in the bookkeeping, nor in the resolution books or any other sources. And that number increased during the eighteenth and nineteenth centuries. There was an evolution in the number of new members who never again appeared in the sources after their first registration. Of the commoners who were registered in the period 1680-1790, about 65 per cent was involved in the common (on the basis of activities in the period 1700-1790). From the last decade of the eighteenth century onwards, however, this percentage started to decline considerably. By the middle of the nineteenth century, less than half of the new members were involved in the common, one way or another. The absence of so many commoners from the records can only to a very limited extent result from gaps in the series of sources. Clearly, something was happening on the common: the proportion of active participants among the total number of members became smaller and smaller. ${ }^{27}$ It also meant, as will be demonstrated further in this article, that the proportion of passive members (those who gained no concrete benefits from the common) was becoming a greater burden over time on the more active participants.

Some individual examples can illustrate the "passive" behaviour of some of the members. Bernardus Mulle became an 'aanborger' in 1804 through his wife Rosa De Schepper, and is a typical example of a passive member. ${ }^{28}$ In the population censuses of 1796 and 1814 he was described as a wage labourer. From other censuses that registered the number of cattle during the 1820s, we know that he owned at least two cows. ${ }^{29}$ Nonetheless, we cannot find any traces of Mulle being active on the common. Distance can hardly have been an argument in this decision, since during the entire period he lived in Assebroek, and the largest part of the pastures was located in that village. The same was true of Franciscus Van den Berghe: $:^{30}$ according to the censuses of 1794 and 1814, he was a wage labourer. The marriage acts record him as a servant. Both contain the same essential information: he worked for wages. He never appeared in the censuses as a cattle owner. In the case of Franciscus this may have been the main reason for his never having been active in Gemene and Loweiden.

According to our information, another passive commoner, Laurentius Van Belleghem, was a wage labourer in 1811 and in $1835 .{ }^{31}$ The records show that he was born in 1778 and was a commons member from 1802 onwards. When he was 34, he did use

\footnotetext{
${ }^{27}$ Considering that we could not retrieve data on the death of all aanborgers, it is not possible to put this proportion of active participants among those who once registered, in relation to the total number of aanborgers at any given moment in time. It can be assumed however that the total number of commoners was growing over time, as the number of newly registered commoners increased as well.

${ }^{28}$ Bernardus Dermulle, commoner from 1804, see CAB, AGL 14, Hoofdboek. Boek van de geslachten van de Gemene- en Loweede 1769-1889.

${ }^{29}$ This becomes clear on the basis of the censuses to be found in Provinciearchief West-Vlaanderen, Modern Archief (2de reeks, TBO7), Nr. 701-708, Numerieke staten van het belastbaar vee (hoornvee, schapen en paarden), 1823.

${ }^{30}$ Franciscus van den Berghe, became aanborger in 1832, see ibid.

${ }^{31}$ Laurentius van Belleghem, became aanborger in 1802, see ibid.
} 
the common in 1812. In the bookkeeping record of July of that year, we find that he had a [lease] on turf. ${ }^{32}$ But after that he simply disappears from the bookkeeping record. Nor does he appear in the village's cattle censuses, which means it was not likely he used the common. It is not a coincidence that the three early nineteenthcentury examples we chose were all aanborgers who lived primarily from wages. The increasing wage dependence of commoners and other villagers influenced their participation in important ways.

A detailed analysis of the exploitation level and the resolution books of Gemene and Loweiden illustrates that the commoners themselves were aware of the potential negative effects of both over- and underexploitation. In the first half of the 18th century commoners did not own enough cattle to prevent undergrazing on the common. Eventually, this could lead to underexploitation and a lack of social control on the use and management of the common. To achieve a constant grazing level of about 150 cattle units, which was the number that could be held in a sustainable way on this size of a meadow, the commons' managers temporarily allowed others to graze their cattle on the common. For this privilege they asked considerable sums, often amounting to more than 20 times the price commoners had to pay to let their cattle graze on the common (see further). Apart from the fact that they simply wanted to seize the opportunity to get some extra income via this way, this decision can be seen as part of the overall management strategy of the commoners to avoid a "tragedy of the commons". Elsewhere I described how the commoners of this particular common effectively supplemented their regulations with a price mechanism to gain control over the exploitation level of the common, and hence were able to prevent the common from the dreaded tragedy (De Moor 2009).

The possibility that commoners entitled to use the common's resources chose not to do so, whether deliberately or because they did not have the means, may have threatened the smooth functioning and even the future of the institution, in different ways. Apart from the potential threat that insufficient cattle is grazed on the common (see above), passivity can also lead to a lesser involvement of the commoners, and weakening social control. This was especially true for an institution like that in our case study which was self-governed and where most decisions were taken by the members themselves. The effect of a large group of passive members cannot be underestimated: it can be assumed that those who do not receive substantial benefits from the commons will not care about the common either, and thus might refrain from reporting abuse or problems on the common. To identify the reasons for the changes in the commoners' participation level and the growing number of passive members, we need to add another, more qualitative dimension to our analysis. Those commoners who did participate could do so in many different ways. A more detailed analysis of the bookkeeping records allows us to distinguish between various types of economic and functional participation. The former refers to any activity noted in the books that involved some sort of economic exchange: from grazing cattle on the common, buying firing wood or peat at "members-only" prices, using the small river along the common for retting flax, to performing jobs such as digging or making fences on the common. Such activities contributed to the commoners' well-being: they could benefit from using the inexpensive pasture or they received wages from the commons' treasurer. The discrepancy between the price commoners paid to be

\footnotetext{
${ }^{32}$ In 1815 he paid his debts (lease) of 1812; see the accounts terminated in 1815, CAB, AGL 108, Rekening 1811-1813.
} 
allowed to graze their cattle on the common and the price non-members were asked (and willing!) to pay for the same benefit gives us a clear indication of the benefits to be reaped as a member. It shows that the benefits must have been substantial, at least in the case when one had cattle to graze on the common. At the same time the eagerness of non-commoners to use the facilities also provided quite some income for the common as a whole. In the first half of the 18th century, to secure a constant grazing level on the common, non-members' cattle were admitted, but only after the non-members paid as much as 22 times what commoners paid. Commoners who did not graze cattle on the common probably missed out on a substantial benefit. By analyzing the commoners' ways of economic participation, it becomes possible to determine what their main interests were.

A variety of "official" functions for the commons was included as functional participation, and some of these were remunerated. Every three years some members of the board were entrusted with daily management of the common; these usually included five hoofdmannen, who were re-elected by the commoners. Those elected to one of the offices not only received wages, but were also accorded higher social status, which was probably an extra incentive for being actively involved. The hoofdmannen were assisted by a treasurer, the lowest paid function. In addition to the official appointment, simple attendance at the annual meetings was also included in our analysis as a form of functional participation. Although commoners were in principle obligated to be present, the accounts show that in most instances some member abstained. Increasingly, the commoners lived further away from the common and found it difficult to appear at the annual meetings. At first the hoofdmannen tried to invite distant commoners by announcing the meetings after mass service in most of the surrounding villages. ${ }^{33}$ In the nineteenth century, however, only churchgoers from neighbouring villages were informed about the meetings and decisions. This change in communication strategy probably also influenced commoners' attendance at meetings, and their participation level in general. In addition to the quantitative analysis of the internal group balance between passive and active members, such changes can give us an idea of the concentration of power within the group of active members. This contributes to our understanding of the decision process on the commons.

Joannes De Schepper, whose family was involved in the common from the second half of the seventeenth century, ${ }^{34}$ is a good example of the diversity of participation among the commoners. Of all the aanborgers his family ever had, he was the most active: even before he officially became a member of the common in 1752, he had been involved as a labourer to help with drainage work on the common. He must have had a good reputation in the village, since he became the treasurer of the common soon after he became a member, and he fulfilled this function almost continuously until 1782. No doubt Joannes had a network of people who elected him to the job because of his main occupation: in the population census of 1748 , he was registered as an innkeeper (and carpenter), which was probably one of the best functions to have in terms of social capital formation. The fact that he managed to

\footnotetext{
${ }^{33}$ See De Moor (2003b, 297-299).

34 Joannes De Schepper: Joannes de Scheppere, commoner from 1752, see CAB, AGL 13, Hoofdboek. Boek van de geslachten van de Gemene en Loweede, 1718-1767 (copy). The first registration of the family De Schepper(e) was Lieven de Scheppere, commoner from 1679 onwards (see CAB, AGL 12, Hoofdboek. Boek van de geslachten van de Gemene en Loweede, 1622-1703).
} 
obtain the job of treasurer year after year by demanding the lowest remuneration for it was probably also related to the benefits he could obtain by providing food and drink at the meetings of the commoners. Combining the job of innkeeper with being the local common's treasurer was clearly a smart way of using your membership. Joannes saw his participation as a source of income, either through his inn or his work for the common, and did not see need to take advantage of the other facilities the common offered him: in all the time he was involved with the common, he never grazed any cattle on it.

In 1831 another Johannes, of the Claeys family, became aanborger, and he became treasurer of the common in 1842. After that we lose track of him in the sources. His father Ignatius had followed a very different course: ${ }^{35}$ for ten years he grazed cattle on the common but never held any office. Another example was Frans Tanghe, also from a family with a long tradition in Gemene and Loweiden: both via his father Jan and his mother Isabelle van Laethem. He became a member in 1843, and thereafter combined functional and economic participation. One-quarter of his registered activities related to leasing out land for cattle rearing and crops. His other activities were related to performing jobs on the common. ${ }^{36}$ From 1868 to 1879 he worked as overseer for the common and as treasurer. In total, his name was mentioned in the records for 36 years, and he was one of the most active commoners of the entire period. $^{37}$

Notwithstanding the potential risks that categorizing commoners involves, it does help to signal an evolution in the participatory behaviour of commoners. One of the most interesting trends is that beginning with the middle of the eighteenth century there was a growing polarization between economic participants and functional participants. At that time nearly half the active commoners combined economic participation with some sort of functional involvement; a century later this was only true for one out of ten commoners. By the middle of the nineteenth century, most commoners (eight out of ten) had become economic participants only, and were no longer involved in the management of the common. ${ }^{38}$

The above described evolution in types of commoners' participation and the declining amount of active participation can be combined with another indicator to show the importance commoners attached to their membership. Combining the participation data with the marriage registers for the villages of Assebroek, Oedelem, and surrounding villages, enables us to estimate the age at subscription of new members. This age is an indicator of the importance a new member (or if he was very young, his parents) attributed to belonging to the common and the community of commoners. It can be assumed that joining the group when a person was very young - early childhood to early teens - indicates the parents' high expectations: becoming a member could offer a son the guarantee of more social security, or at least a

\footnotetext{
${ }^{35}$ Joannes Claeys, became aanborger in 1831, see ibid and Ignatius Claeys, became aanborger in 1821 , see ibid.

${ }^{36}$ Frans Tanghe did not have any cattle on the common because by the time of his first participation the system of 'schatgelden' was already abolished. This was a system in which a given sum of money was paid per head of cattle grazed on the common. The land he leased from the common could however have been used for pasturing.

${ }^{37}$ Frans Tanghe participated on average 3.78 times a year (during his membership), which included 2.59 economic participations between 1836 and 1879 .

${ }^{38}$ De Moor (2003b, 273-274).
} 
source of income and a network that could be called upon in times of trouble. Late subscriptions were more likely if a man became a member via his wife, but they could also mean lower expectations for professional life. The reference point used here is the time when a son began to live his life independent of his parents. In a rural society such a marker would be marriage, which in areas with neo-locality such as West-Flanders was the same as setting up an independent business, usually a farm. ${ }^{39}$

Since it was not possible to retrieve for all commoners both the age at subscription and the age at marriage, we used a sample of nearly 600 commoners to calculate the average age at subscription, and compared this with the average age at marriage for the region. The sample was selected on the basis of availability of data: for some commoners we simply had more information than for others, and for some the date of birth could simply not be found. The search for these data was then extended this from the close of the eighteenth century through the entire nineteenth century. ${ }^{40}$

The sample shows that the average age commoners became members gradually increased in the course of the nineteenth century. Around the end of the eighteenth century the average new commoner was 20 years old; by the first decade of the nineteenth century the age at subscription averaged nearly 30 . The average age remained under 30 until the middle of the nineteenth century, but thereafter it rose again, and around 1880 the average was 40 . In the course of time, potential aanborgers postponed their actual subscription to later in life. From the middle of the nineteenth century, young men usually joined the commons after their marriage, and the average age at first marriage (for men) at that time was around 30. By the end of the nineteenth century, the average marriage age had decreased a few years, but the age at subscription remained as high. This evolution indicates that commoners started to become members of the common at a different point in their life course: if commoners did not find it necessary to claim their right before they were 40, we can assume that they did not consider the commons resources and facilities vital for their professional activities. Or it means that they did not have the means to participate, perhaps because they did not have cattle to graze.

We have now provided several indications that something was happening that deeply influenced the commoners' behavioural strategy: an increasing number of commoners did not use their rights actively, there was a growing gap between users and rulers, and new members were joining when they were older. By linking the available information in the sources on Gemene and Loweiden to other information, such as the population and economic censuses, we can conclude that the above changes may have been related to the changing occupational background of commoners. One very relevant occupational indicator was the extent to which commoners were bound to agriculture as a source of income. Independent, selfsustaining small farmers especially benefited from the common. They would have primarily focused on mixed farming, and needed the grazing facilities offered by the common offered. Maintaining cattle was an essential part of the mixed farming chain, as it provided the manure necessary to fertilize the arable land. It was not until the

\footnotetext{
${ }^{39}$ Although it should also be mentioned that it was not unlikely youngsters left the parental home to work as servants before marriage, which was quite typical for this part of Europe. See De Moor and Van Zanden (2005) and Smith (1979). .

${ }^{40}$ We do not have sufficiently reliable data for the rest of the eighteenth century.
} 
mid-nineteenth century that fertilizers such as guano would be imported in large quantities and that chalk deposits would be developed, solving part of the fertilization bottleneck of mixed farming. Thus, in seeking to explain the changes in the commoners' behavioural strategy, we should concentrate on the farmers among the commoners.

The analysis shows that just over 50 per cent of the commoners who became members in the first half of the eighteenth century were registered as farmers, nearly 19 per cent as agricultural wage labourers, and about 14 per cent worked as wage labourers outside agriculture..$^{41}$ Thereafter, the number of commoners registered as farmers dropped significantly. In the second half of the eighteenth century, this group accounted for only 24 per cent; among the commoners registered in the first half of the nineteenth century, only one out of five was a farmer but nearly four out of ten were registered as agricultural labourers. Together with the other wage-labouring commoners, they accounted for two-thirds of all commoners. In the second half of the nineteenth century, those engaged in wage labour dropped to 44 per cent (including agricultural labourers), but the proportion of farmers did not increase to more than one-quarter of the group. Although sometimes confusing statements in the sources made categorizing the commoners' occupational status difficult, there was a clear evolution in the social-economic background of the commoners: wage-dependent commoners increasingly replaced farmers among commoners. ${ }^{42}{ }^{43}$ This evolution is no different from the general trend towards more wage dependency in this period elsewhere in Flanders.

The example of Andreas De Rijcker, born in 1763 and registered as a commoner in 1786, illustrates the evolution from farmer to wage labourer that many commoners experienced in this period. ${ }^{44}$ Andreas came from a family that had had four ancestors registered as commoners in the sixteenth century. ${ }^{45}$ And in the nineteenth century, after Andreas, there were Bruno, Henri, Louis, Bernard, Félix, and others of the same

\footnotetext{
${ }^{41}$ These results are entirely based on a dataset comprised of 64 aanborgers, who became commoners in the first half of the eighteenth century and who appeared in the population census of 1748. No other census material was used. Of these 64,60 were known as active on the common, which is not surprising considering the high participation level around this time, as mentioned earlier in this article. The other percentages for the periods thereafter are based on a large number of diverse sources, ranging from registers of birth/baptism (for occupations of parents who were aanborgers), marriage and death/burial, composed by the parish priest in the Ancien Regime and by the local government thereafter. In combination with the data on the registration of the commoners retrieved from the hoofdboeken, we obtained a sample of 710 aanborgers for the whole period 1700-1900, of whom 418 can be considered as active.

${ }^{42}$ These data were collected on the basis of a variety of sources: resolution books, bookkeeping records, hoofdboeken, parish registers, population registers, demographic and economic censuses.

${ }^{43}$ For 1748 we can compare the occupational structure of the commoners to the overall occupational structure of the villages Assebroek and Oedelem. $65 \%$ of the inhabitants of these villages were active in agriculture either as farmers $(23 \%$ of the total) or as wage labourers $(41 \%$ of the total), which is only slightly less than the $69 \%$ of the aanborgers active in agriculture in 1748 . We can do this because all occupational information on the commoners for the period 1700-1750 is based on the 1748 census. See the above footnotes. For the other periods such a comparison would not be reliable, as data on the commoners' backgrounds came from various sources.

${ }^{44}$ Andreas de Rijckere, a commoner from 1757, see CAB, AGL 13, Hoofdboek. Boek van de geslachten van de Gemene en Loweede, 1718-1767 (copy).

45 Jan de Rijckere, commoner from 1698, see CAB, AGL 12 Hoofdboek. Boek van de geslachten van de Gemene en Loweede, 1622-1703 and Pieter de Rijcker, commoner from 1779, see CAB, AGL 14.
} 
lineage. ${ }^{46}$ The De Rijcker family was among the most active group on the common, which makes them a good 'barometer' for revealing how the changes came about. The family had a clear interest in the economic advantages of the common, but was less concerned about being elected to an office (except for Adriaen De Rijckere, ${ }^{47}$ who in 1843 would become one of the hoofdmannen). Three years after his registration, Andreas began to use his rights to the common: ${ }^{48}$ between 1789 and 1827 he usually grazed one cow on the common, sometimes also a swine. In 1813 and 1814 he had two cows and one horse on the common. According to the censuses, he already had a horse at the end of the eighteenth century, but by the 1820s he was back to one single cow, which he placed on the common. And after that he lost even more: in 1827, when he was 64 years old, Andreas was last mentioned in the bookkeeping record as a debtor. His worsening situation can also be shown from the occupational category mentioned for him in the censuses. While he was still listed as a farmer in 1796, in 1814 and 1826 he was registered as a labourer. The other members of the family for whom we could retrieve occupations were nearly all registered as working for wages. ${ }^{49}$

Thus we see that the social and economic background of commoners changed dramatically from the late eighteenth century onwards. The decrease in the number of farmers -among both active and passive commoners- was part of a more general proletarization of the Flemish countryside in this period. This process influenced commoners' participation and the way they participated. Yet, when we consider the commoners' behaviour and the possible reasons why that behaviour changed over time, if their individual advantages had become so limited, why did they still register as members and pay the 1 pound for a subscription? Especially commoners whose membership rights were derived from in-laws may have been eager to register. The percentage of those who became members in that way increased over time, from 21 per cent of all new members in the period 1775 to 1799 to 38 per cent in the period 1875-1900. The total number of new members increased from 31 new members in the earlier period to 217 in the later one, which indicates that within the village communities, the need for the common was still very great, although it may have been less directly linked to the family farm, which was still very important. Many, it seems became members to secure use-rights for future generations.

\section{The consequences of changing power balances on the common}

This analysis has so far shown that commoners followed different strategies, that their choices were influenced by social and economic changes, and that their individual strategies represented a considerable change in the extent and way commoners were active on the common. Another consequence of the shift in participant profiles was a growing polarization amongst the group of active participants, between the simple "users" and "managers". The internal power balances changed over time, from a fairly democratic regime to a system in which

\footnotetext{
${ }^{46}$ Bruno de Rijcker, commoner from 1787 (CAB, AGL 14), Henricus de Rycker, commoner from in 1820 (CAB, AGL 14), Ludovicus de Rycker, commoner from 1825 (idem), Bernardus de Rijckere, commoner from 1833 onwards (idem), Felix de Rijckere, who became commoner in 1839 (idem).

${ }^{47}$ We deal here with Adriaen de Rijcker, who became aanborger in 1728 (CAB, AGL 13), and who was also the grandfather of Andreas de Rijcker, who became aanborger in 1786 (CAB, AGL 14).

${ }^{48}$ This part refers to Andreas de Rijcker, aanborger from 1786 onwards (CAB, AGL 14).

${ }^{49}$ We do not know the occupation of Adriaen de Rijcker, who became aanborger in 1728 (CAB, AGL 13).
} 
decisions were increasingly taken by an administrative elite, without much interference by those who actually used the common, the small and medium farmers. The growing passivity of the commoners, combined with the increasing polarization between "economic users" and administrators, led to an imbalance in resource use and the way the resources were managed.

First, the data we found for Gemene and Loweiden show that imbalances in power relations may have had serious consequences on the use of the commons' natural resources. Commoners could use the meadows for grazing their cattle by paying per head. Through this system it became possible for the managers of the common to control the total number of cattle units on the common, which was very useful in preventing overexploitation of resources: if use of the common became too great, the prices per head of cattle were raised. Conversely, if commoners did not have sufficient cattle to graze on the common, prices were reduced. Moreover, in periods when there was a serious lack of cattle to maintain the necessary level of grazing, people who were not commoners were sometimes allowed to graze cattle on the common. In the 1840s, however, this highly efficient system was threatened. On the one hand, there was increasing pressure from passive members, among whom many were too poor to make good use of their membership. It is quite likely that they used their precarious economic position as an argument to move the other commoners towards freeing more pasture land for other means. On the other hand, a small number of commoners had the power to change the system entirely. As a result, this is what happened. In the 1840s the system that had long been used to regulate the number of cattle on the common was replaced by a lease system. Commoners could apply to lease a plot of land, and use it according to their needs. In the 1820s, part of the land had also been turned into arable land, which should have made it more attractive for non-cattle owners as well. Restrictions on how the land was used became less strict from the 1840s onwards, making it more likely that the former restrictions on the number of cattle to be allowed on the common were no longer applied. It is possible to speculate about why the commoners in such times of hardship did not decide to abolish the communal system altogether. Apart from a desire to maintain their rights to the common as social security, there may have been other issues at stake. One of the advantages a commoner may have found was a certain type of transaction cost. Elaine Tan, in her article "The bull is half the herd": property rights and enclosures in England, 1750-1850', claims that common fields reduced the transaction costs for a commoners to maintain a cow by lowering the cost of insemination. After enclosure, the cost of maintaining a cow increased among small owners who, unlike large farmers, could neither jointly own the bull and the cow, nor lease the male easily. The minimum acreage required to restore cow keepers to their pre-enclosure economic position indicates that many commoners who were given some land in settlement were inadequately compensated for the change in property rights. Thus, if the number of small cattle owners among the commoners of the Flemish common discussed in this article increased, the advantage of keeping some of the land in common could have been relatively important.

In the 1840s and 1850s the common also came under increasing pressure from the local and national governments, leading to the forced abdication of the management board in 1862. The control over the common was taken out of the hands of the commoners until 1882, when the commoners won a court case against the 
municipalities of Assebroek and Oedelem. Gemene and Loweiden are one of the very few commons in Flanders that survived this period. The only reason for this survival may have been the legal support it received from a local priest, Canon Andries, who was able to trace all the documents (back to the sixteenth century) that proved the commoners' rights, even in the new legal system of the nineteenth century. In 1847 the government passed a new law, ostensibly to encourage reclamation of the remaining waste lands in Flanders, but it actually provided the local governments with an instrument to dissolve all common property in their territory and sell the land for their own benefit. Long before 1847, the eighteenth and early nineteenth-century laws had tried to dissolve the commons on Belgian territory, but to little avail (De Moor 2003a). This forced dissolution of land held in common became legally possible with the introduction of the new civil code, which under article 542 held that all common property was communal property. Local governments referred to this article and had the support of the national and provincial governments when trying to seize commoners' land. With the crisis of 1846 that drove many Belgians into poverty, the government saw a new opportunity to dissolve the commons, under the excuse that it would be beneficial for agricultural output. Great pressure was placed on local governments to sell all common property on their territory. If no action was taken, the government could even proceed to a forced selling of the common. In areas with vast stretches of common land, such as in the Kempen, a sandy area north of Antwerp, the commoners saw no chance of participating in the bidding for the common land that was being auctioned, except when they joined forces to buy a plot of land collectively. Usually the land was bought by the urban bourgeoisie who speculated on the projected profits to be gained from its future cultivation (Van Looveren 1983). Although the land did rise in price as a result of infrastructure efforts by the government (including digging canals through the Kempen), it never became the agricultural miracle that had been hoped for.

This fact that decisions about how to use the resources of the common were now largely made by leaseholders, must have led to reduced social control by the commoners themselves. In general, sociologists assume that a low participation level can have serious consequences for the functioning of an institution such as a common. When less active participants reduce already suboptimal social control, it can mean such "free-riding" is less easily spotted by others. The commoners were aware of this potential risk; nevertheless, it was not unusual to find systems that sanctioned those who saw an infraction of the regulation but did not report it to the management of the common. ${ }^{50}$ To make the control system water-tight, young cow herders were often recruited to keep an eye on the common and its users while working, as a form of extra control.

It is logical that the commoners' reduced participation must have also led to less strict social controls among the active participants. The commoners of Gemene and Loweiden tried to solve this problem by calling in external controllers. From the late eighteenth century onwards they paid the local constable to inspect the common. ${ }^{51}$

\footnotetext{
${ }^{50}$ For many references to the regulation, see De Moor (2002 and 2005) for Flanders. For examples of other Western European countries, see the other chapters in De Moor, Shaw-Taylor, and Warde (2002a)..

${ }^{51}$ Experimental research claims that inspection and sanctioning of behaviour does not necessarily encourage people to behave better. In this sense it can be questioned whether external monitoring/inspection can be considered a valuable alternative for social control (Ostman 1998).
} 
Increased involvement of external controllers may have also reflected the increasing attempts of local government to interfere in the management of the common. In the period when the common was put under supervision of a sequester (1862-1882), the extra expenditure to control the common was considered completely superfluous. ${ }^{52}$ When the common was leased out, the new management was convinced that, just as with "normal" private property arrangements, every leaseholder should be responsible for managing his own plot of land, which was completely in line with the liberal ideas of nineteenth-century anti-commons legislation.

\section{CONCLUSION}

This article has demonstrated the potential benefits of a detailed analysis of the behaviour of commoners as users, and also precisely when and why they ceased to use the common: it can help us to explain the deeper motivations of commoners to use the commons' facilities, and this again can explain why the use and importance of commons changed over time. This article is based on a specific case study to describe several changes in commoners' behaviour during the eighteenth and nineteenth centuries. The case study is based on records from Gemene and Loweiden, not far from the eastern city gates of Bruges. First, we saw a growing number of passive members, who, by the nineteenth century, probably had a significant influence on the decision-making of the common. Second, among the users of the common a clear polarization between those who were involved in the common for economic reasons and those who acted as 'managers' was found. While originally managers were also usually users, the two groups became increasingly distinct from one another. Moreover, by the middle of the nineteenth century, the age at which commoners were registered as members was considerably older than in the eighteenth century, suggesting that the immediate need to use the common had become less important. These three developments - activity rate, type of participation, and age of subscription - can be considered indicators of change in the use of resources, the internal power balance, and the social control on use. As the common became less used by cattle owners there were more possibilities for users without cattle; this process also included the abolition of the efficient system of payment per head of cattle. This change in management system may have weakened the commoners' ability to oppose to the local governments' interference. The constable of the local government had already been asked to control the use of the common. It is likely that such control was needed to compensate for reduced social control, a function of the less regular use by the commoners and thus also their reduced physical presence on the common. The main cause we have identified for the commoners' changing behaviour was their proletarization, which was apparent in their increasing wage dependence. Commoners were to lesser extent independent farmers, and their number of cattle per farmer had diminished greatly over time. This particular case study provides a unique insight into the workings of a preindustrial common, thanks to the availability of a large set of account books for an impressively long period when major changes took place among commoners and in society as a whole. Although bookkeeping records are available for other commons that were managed more independently, it might not be possible to develop a similar dataset and conduct similar analyses for these other commons. To be sure, there are

\footnotetext{
${ }^{52}$ It is unclear - in the absence of accounts for the period 1843-1868 - whether the committee in charge of the management of the common recorded this expense every year.
} 
other forms of institutions for collective action, such as guilds, for studying group heterogeneity and size in similar detail. Elsewhere, I have argued that the commons can be considered the rural counterparts of guilds, in view of their many similar objectives, organization, rise, and decline. ${ }^{53}$ Our understanding of internal regulation by cooperating individuals, whether living in the countryside or in urban environments, could benefit from similar analyses in the future.

\section{Sources $^{54}$}

\section{CAB: City Archives of Bruges (Stadsarchief Brugge), Archief van de Gemene en Looweiden}

2 Copy (late 17th century) of part of the confirmation letters of Karel De Stoute (translated from the original text of 1475, vertaling van de oorspronkelijke Franse tekst uit 1475 'Recueil - Fait en 1514, des coutumes, ordonnances, privilèges, etc.' van het archief van de Gemene en Loweiden

12 Book of registrated commoners 'Hoofdboek. Boek van de geslachten van de Gemene en Loweede', 1622-1703

13 Book of registrated commoners 'Hoofdboek. Boek van de geslachten van de Gemene en Loweede, 1718-1767', copy

14 Book of registrated commoners 'Hoofdboek. Boek van de geslachten van de Gemene en Loweede 1769-1889'

$59 \quad$ Account 1699-1702; afgesloten in 1702

$60 \quad$ Account 1699-1702; dubbel, onvolledig

$61 \quad$ Extract from the account closed in 1699

$62 \quad$ Account 1704-1706; closed in 1707

63 Account 1703-1705; dubbel

64 Account 1707-1709; closed in 1710

$65 \quad$ Account 1707-1709; dubbel

$66 \quad$ Account 1710-1712; onvolledig

$67 \quad$ Account 1712-1717; onvolledig

68 Account 1718-1720; closed in 1722

$69 \quad$ Account 1718; onvolledig

$70 \quad$ Account book "Handboek vanden ontvanger van $1^{\circ} \mathrm{d}$ e akkoorden over het pastureren van de onvrije beesten $2^{\circ}$ de schatge lden gestemd over de beesten der aanborgers, van 1719-1732".

$71 \quad$ Account 1721-1723; closed in 1725

$72 \quad$ Account 1721-1723; dubbel

73 Account 1721-1723; dubbel

$74 \quad$ Account 1724-1726; closed in 1728

$75 \quad$ Account 1724-1726; dubbel

$76 \quad$ Part of account 1724-26

77 Account 1727-1729; closed in 1731

78 Account 1730-1732; closed in 1734

$79 \quad$ Account 1733-1735; closed in 1737

\footnotetext{
${ }^{53}$ See T. De Moor, (2008).

${ }^{54}$ It is impossible to mention here all the sources used for this article. A great deal of information was also derived from agricultural, population, and professional censuses and demographic sources such as marriage registers. For a complete overview of all the sources used, see De Moor (2003b).
} 


\begin{tabular}{|c|c|}
\hline 80 & Part of account 1734 \\
\hline 81 & Account 1736-1738; closed in 1740 \\
\hline 82 & Account 1739-1741; closed in 1743 \\
\hline 83 & Account $1742-1744 ;$ closed in 1746 \\
\hline 84 & Account 1745-1747; closed in 1749 \\
\hline 85 & Account 1748-1750; closed in 1752 \\
\hline 86 & Account 1751-1753; closed in 1755 \\
\hline 87 & Account 1751-1753; dubbel \\
\hline 88 & Account 1754-1756; closed in 1758 \\
\hline 89 & Account 1754-1756; dubbel \\
\hline 90 & Account 1757-1759; closed in 1761 \\
\hline 91 & Account 1757-1759; dubbel \\
\hline 92 & Account 1760-1762; closed in 1764 \\
\hline 93 & Account 1760-1762; dubbel \\
\hline 94 & Account 1763-1765; closed in 1767 \\
\hline 95 & Account 1763-1765 \\
\hline 96 & Account 1766-1768, closed in 1770 \\
\hline 97 & Account 1769-1771; closed in 1773, copy \\
\hline 98 & Account $1772-1774 ;$ closed in 1776 \\
\hline 99 & Account 1772-1774; dubbel \\
\hline 100 & Account 1775-1777; closed in 1779 \\
\hline 101 & Account 1775-1777; dubbel \\
\hline 102 & Account 1778-1780; closed in 1782 \\
\hline 103 & Account 1778-1780; dubbel \\
\hline 104 & Account 1781-1783; closed in 1785 \\
\hline 105 & Account 1784-1786; closed in 1788 \\
\hline 106 & Account 1787-1789; closed in 1791 \\
\hline 107 & Account 1787-1789; dubbel \\
\hline 108 & Account 1811-1813; closed in 1815 \\
\hline 109 & Account 1818-1820; closed in 1821 \\
\hline 110 & Account 1821-1823; closed in 1824 \\
\hline 111 & Account 1824-1826; closed in 1827 \\
\hline 112 & Account 1827-1828; closed in 1828 \\
\hline 113 & Account 1828-1829; closed in 1831 \\
\hline 114 & Account 1831-1832; closed in 1833 \\
\hline 115 & Account 1833-1835; closed in 1836 (dubbel) \\
\hline 116 & Account 1836-1838; closed in 1839 \\
\hline 117 & Account 1839-1841: closed in 1842 \\
\hline 118 & Account 1863-1868; closed in 1885 (sic!) \\
\hline 119 & Account 1868-1882; closed in 1884 \\
\hline 120 & Account 1882-1886; closed in 1886 \\
\hline 121 & Account 1886-1889; closed in 1889 \\
\hline 122 & Account 1889-1892; closed in 1892 \\
\hline 123 & Account 1892-1895; closed in 1898 \\
\hline 124 & Account 1895-1898; closed in 1898 \\
\hline
\end{tabular}

\section{National Archive Bruges (Rijksarchief Brugge)}

Aanwinsten 1984, 68, Bouck van de geslachten van de Gemeene weede. Register van inschrijvingen als aanborger van 1515 tot 1703 ; 
Provinciearchief West-Vlaanderen, Modern Archief 2de reeks (TBO7), Nr. 701-708, Numerieke staten van het belastbaar vee (hoornvee, schapen en paarden), 1823. 


\section{REFERENCES}

Brewer, Marilynn B., and Roderick M. Kramer. 1986. Choice behavior in social dilemmas: Effects of social identity, group size, and decision framing. Journal of Personality and Social Psychology 50 (3):543-549.

Congost, Rosa, and José Miguel Lana. 2007. Campos cerrados, debates abiertos. análisis histórico y propriedad de la tierra en Europa (siglos XVI-XIX). Pamplona: Universidad Pública de Navarra.

Cox, S. J. B. 1985. No tragedy on the commons. Environmental Ethics 7:49-61.

De Bo, M. 1892. Westvlaams idioticon. Gent: A. Siffer.

De Moor, M. 2003(a). Les terres communes en belgique. In Les propriétés collectives 1750-1914. Les attaques du libéralisme en Europe et Amérique latine, eds. M. -D Demélas, N. Vivier, 119-138. Rennes: Presses Universitaires de Rennes.

2002. Common land and common rights in flanders. In The management of common land in north west europe, c. 1500-1850., eds. Martina De Moor, Leigh Shaw-Taylor and Paul Warde, 113-142. Turnhout: Brepols.

De Moor, Martina. 2005. De Gemene en Loweiden in Assebroek als één van de laatste gemene gronden in Vlaanderen. Beknopte geschiedenis van de instelling en inventaris van het archief. Handelingen Van Het Genootschap Voor Geschiedenis, Gesticht Onder De Benaming 'Société d'Émulation' Te Brugge: Driemaandelijks Tijdschrift Voor De Studie Van Geschiedenis En Oudheden Van Vlaanderen 142 (1-2):3-45.

2003(b). Tot proffijt van de ghemeensaemheijt. Gebruik, gebruikers en beheer van gemene gronden in zandig vlaanderen, 18de en 19de eeuw. PhD diss., History, Ghent University.

De Moor, Martina, Leigh Shaw-Taylor, and Paul Warde. 2002(a). The management of common land in north west Europe, c.1500-1850. CORN publication series 8. Turnhout: Brepols.

De Moor, Martina, Leigh Shaw-Taylor, and Paul Warde. 2002(b). Comparing the historical commons of north west Europe. An introduction. In The management of common land in north west Europe, c. 1500-1850., eds. Martina De Moor, Leigh Shaw-Taylor and Paul Warde, 15-32. Turnhout: Brepols.

De Moor, Tine. 2009. Avoiding tragedies. A Flemish common and its commoners under the pressure of social and economic change during the eighteenth century. Economic History Review 62 (1):1-22. Also to be found online at: http://onlinelibrary.wiley.com/doi/10.1111/j.1468-0289.2008.00426.x/full

2008. The Silent Revolution: A new perspective on the emergence of commons, guilds, and other forms of corporate collective action in Western 
Europe. International Review of Social History 53 (Suppl.):179-212. Also to be found online at:

http://journals.cambridge.org/action/displayAbstract?aid=2690472

2007. La función del comun. la trayectoria de un comunal en flandes durante los siglos XVIII y XIX. In Campos cerrados, debates abiertos. análisis histórico y propriedad de la tierra en europa (siglos XVI-XIX), eds. Rosa Congost, José Miguel Lana. Pamplona: Universidad Pública de Navarra.

De Moor, Tine, and Jan Luiten Van Zanden. 2010. Girlpower. the european marriage pattern (EMP) and the development of labour markets in the north sea region during the late medieval and early modern period. Economic History Review 63 (1):1-33. Also to be found online at: http://journals.cambridge.org/action/displayAbstract?aid=2690472

Hammond, J. L., and Barbara Bradby Hammond. 1995. The labourer, 1760-1832, Stroud : Alan Sutton.

Jager, W., M. A. Janssen, H. J. M. De Vries, J. De Greef, and C. A. J. Vlek. 2000. Behaviour in commons dilemmas: Homo economicus and homo psychologicus in an ecological-economic model. Ecological Economics 35: 357-79.

Oliver, Pamela E., and Gerald Marwell. 1988. The paradox of group size in collective action: A theory of the critical mass. II. American Sociological Review 53 (1):1-8.

Olson, M. 1965. The logic of collective action: Public goods and the theory of groups. Cambridge, MA: Harvard University Press.

Ostmann, A. 1998. External control may destroy the commons. Rationality and Society 10:103-122.

Poteete, Amy R., and E. Ostrom. 2004. Heterogeneity, group size and collective action : The role of institutions in forest management. Development and Change 35 (3):435-462. Also to be found online at:

http://onlinelibrary.wiley.com/doi/10.1111/j.1467-7660.2004.00360.x/abstract

Shaw-Taylor, Leigh. 2002. The management of common land in the lowlands of southern england circa 1500 to circa 1850. In The management of common land in north west europe, c. 1500-1850., eds. Martina De Moor, Leigh Shaw-Taylor and Paul Warde, 59-86. Turnhout: Brepols.

Smith, Richard. 1979. Some reflections on the evidence for the origins of the 'european marriage pattern' in england. In The sociology of the family: New directions for britain. sociological review monograph 28., ed. C. Harris, 74-112.

Van Looveren, E. 1983. De privatisering van de gemeentegronden in de provincie antwerpen: Vier case studies. Bijdragen Hertogdom Brabant LXVI:189-219. 
. De gemeentegronden in de provincie antwerpen: De privatisering van een eeuwenoud gemeeschapsgoed. een totaalbeeld en vier case studies. PhD dissertation. K.U.L.. 